\title{
Synchronising the availability of amino acids and glucose increases protein retention in pigs
}

\author{
J. J. G. C. van den Borne ${ }^{1 \dagger}$, J. W. Schrama ${ }^{1,2 \ddagger}$, M. J. W. Heetkamp ${ }^{2}$, M. W. A. Verstegen ${ }^{1}$ \\ and W. J. J. Gerrits ${ }^{1,2}$ \\ ${ }^{1}$ Animal Nutrition Group and; ${ }^{2}$ Adaptation Physiology Group, Department of Animal Sciences, Wageningen University, P.0. Box 338, 6700 AH Wageningen, \\ The Netherlands
}

(Received 16 November 2006; Accepted 27 February 2007)

Effects of synchronising the availability of amino acids and glucose within a day on protein and energy metabolism were studied in growing pigs. Ten pigs of on average 54 (s.e. 1.0) kg live weight were assigned to each of two dietary treatments (synchronous v. asynchronous nutrient supply) in a change-over design. On the synchronous treatment (SYN), pigs received two balanced meals: one at $0800 \mathrm{~h}$ and one at $1600 \mathrm{~h}$. On the asynchronous treatment (ASYN), pigs received virtually all protein at $0800 \mathrm{~h}$ and all carbohydrates at $1600 \mathrm{~h}$. The dietary supply of ingredients and nutrients to pigs was similar for both treatments. Pigs were housed individually in respiration chambers. Faecal apparent nutrient digestibility was determined and nitrogen and energy balances were measured. Faecal apparent digestibility of energy, organic matter and non-starch polysaccharides was higher $(\mathrm{P}<0.05)$ for SYN than for ASYN. The efficiency of utilisation of digestible protein with protein gain was higher $(\mathrm{P}=0.001)$ for $S Y N(56.7 \%)$ than for ASYN (47.1\%). The substantial decrease $(\mathrm{P}<0.05)$ in respiratory quotient and ${ }^{13} \mathrm{C}$ enrichment of the expired $\mathrm{CO}_{2}$ after the morning meal indicated higher amino acid oxidation for ASYN than for SYN. Heat production and energy retention as fat were not affected by nutrient synchrony. In conclusion, an asynchronous availability of glucose and amino acids within a day increases amino acid oxidation, resulting in a substantial reduction in protein utilisation but with virtually no effect on fat retention.

Keywords: carbohydrates, energy, nutrient synchrony, pigs, protein

\section{Introduction}

A balanced supply of amino acids and energy-yielding nutrients is required for optimal protein deposition in growing animals. The relationship between digestible energy supply and protein deposition was described (Campbell and Taverner, 1988; Gerrits et al., 1996; Eits et al., 2002) and included in feed evaluation systems and mechanistic growth simulation models for many animal species. Requirements for protein and energy are expressed as daily means in current feed evaluation systems, and a lack of concurrent availability of amino acids and proteinfree energy within a day is usually assumed not to hamper protein utilisation.

The post-absorptive availability of amino acids is, however, not always in synchrony with that of non-protein energy (i.e. mainly glucose). In this perspective, nutrient asynchrony is defined as a (partial) separation of amino

\footnotetext{
† E-mail: joost.vandenborne@wur.nl

FPresent address: Aquaculture and Fisheries Group, Department of Animal Sciences, Wageningen University, The Netherlands.
}

acid and glucose availability in time. Asynchronous nutrient absorption patterns can be induced by either a separated supply of protein and carbohydrates (Barja et al., 1972; Arnal et al., 2000) or by formulating diets using ingredients with different kinetics of digestion and absorption (Metges et al., 2000; Englyst et al., 2003; Mosoni and Patureau-Mirand, 2003). Moreover, the effects of the kinetics of absorption of dietary ingredients can vary between species, because the digestive system differs and particular ingredients are used in practical diets for various species. In preruminant calves, for example, skimmed milk protein, coagulates in the abomasum, resulting in a delayed amino acid absorption compared to glucose (Longenbach and Heinrichs, 1997). Delayed portal glucose appearance in pigs fed resistant starches compared with those fed pregelatinised starch also changes the synchrony between glucose and amino acids (Cummings and Englyst, 1995; Van der Meulen et al., 1997).

The effects of nutrient asynchrony have to some extent been addressed in early literature (e.g. Munro, 1964), generally reporting a decrease in the efficiency of protein 
utilisation (Larson and Chaikoff, 1937; Cuthbertson and Munro, 1939; Cuthbertson et al., 1940). These studies, however, included only non-growing animals and humans. In growing pigs, a partial separation of protein and carbohydrate intake within a day did not result in significant changes in protein utilisation (Eggert et al., 1953; Yeo and Chamberlain, 1966), whereas nutrient asynchrony increased urea production in lambs (Randles, 2001). The consequences of a (virtually) complete nutrient asynchrony on protein and energy metabolism, however, remain to be determined in growing animals. Possibly, there may even be benefits of inducing nutrient asynchrony, because it was recently shown in milk-fed calves that protein utilisation was unaffected, but that fat deposition increased substantially, with increasing nutrient asynchrony (Van den Borne et al., 2006). Therefore, effects of a (virtually) complete separation need to be studied for quantifying the potential impact of nutrient asynchrony on protein utilisation in growing animals.

In this study, it is hypothesised that the efficiency of protein utilisation for growth in pigs may decrease with a virtually complete separation of dietary protein and carbohydrate intake. The net effect on fat deposition will depend on the balance of hypothesised increases and decreases in fat deposition after the carbohydrate diet and protein diet respectively. In this study, effects of synchronising amino acid and glucose availability on protein and energy metabolism were therefore quantified.

\section{Material and methods}

Animals, treatments and diets

Ten crossbred barrows ([Finnish Landrace $\times$ Great Yorkshire] $\times$ Tybor-G) of approximately $50 \mathrm{~kg}$ live weight

Table 1 Experimental design; distribution of the total nutrient intake over two daily meals for synchronously and asynchronously fed pigs ${ }^{\dagger}$

\begin{tabular}{lcc}
\hline \hline & \multicolumn{2}{c}{ Treatment $\left(\mathrm{g} / \mathrm{kg} \mathrm{BW}^{0.75}\right)$} \\
\cline { 2 - 3 } & Synchronous & Asynchronous \\
\hline Daily intake & & \\
$\quad$ Crude protein & 16.8 & 16.8 \\
Starch & 44.5 & 44.5 \\
Crude fat & 4.4 & 4.4 \\
Gross energy $\left(\mathrm{kJ} / \mathrm{kg} \mathrm{BW}^{0.75}\right)$ & 1449 & 1449 \\
Morning meal $(0800 \mathrm{~h})$ & & \\
Crude protein & 5.5 & 16.0 \\
Starch & 14.6 & 0 \\
Crude fat & 1.5 & 1.7 \\
Gross energy $\left(\mathrm{kJ} / \mathrm{kg} \mathrm{BW}^{0.75}\right)$ & 444 & 444 \\
Afternoon meal $(1600 \mathrm{~h})$ & 11.3 & 0.8 \\
Crude protein & 29.9 & 44.5 \\
Starch & 3.0 & 2.7 \\
Crude fat & 905 & 905 \\
Gross energy $(\mathrm{kJ} / \mathrm{kg} \mathrm{BW.75})$ & & \\
\hline \hline
\end{tabular}

${ }^{\dagger}$ Based on calculated values. were used in five replicates of two pigs each. Each replicate consisted of two experimental periods of 7 days each. Within each experimental period, pigs were assigned to one of two treatments in a change-over design: a synchronous supply of protein and starch (SYN) or an asynchronous supply of protein and starch (ASYN) (Table 1). The daily supply of nutrients and ingredients was similar for both treatments. A contrast was created in the distribution of the nutrient intake over the two daily meals (at $0800 \mathrm{~h}$ and at $1600 \mathrm{~h}$ ). Pigs assigned to SYN received a synchronised diet at $0800 \mathrm{~h}$ and at $1600 \mathrm{~h}$, involving an identical composition of both meals. For ASYN, protein and starch intake were as much as possible separated between the two daily meals. This meant that pigs assigned to ASYN were to receive $95 \%$ of the daily protein and $0 \%$ of the daily starch at $0800 \mathrm{~h}$ and $5 \%$ of the daily protein and $100 \%$ of the daily starch at $1600 \mathrm{~h}$ (Table 1).

The protein and carbohydrate diets were formulated separately (i.e. basal diets) (Table 2) and the synchronous diet was formulated by mixing these two in a ratio of 1:2.6. The gross energy intakes at 0800 and $1600 \mathrm{~h}$ were equal between treatments and contributed 33 and $67 \%$ to the daily gross energy intake, respectively. The basal diets were formulated to differ in ${ }^{13} \mathrm{C}$ natural abundance (1.0952 atom \% and 1.0814 atom \% for the protein and the carbohydrate diet, respectively). The maize starch and maize oil were the only naturally ${ }^{13} \mathrm{C}$ enriched ingredients. Measuring ${ }^{13} \mathrm{C}$ enrichment of $\mathrm{CO}_{2}$ in the expired air allowed an improved specification of the contribution of different nutrients to total nutrient oxidation.

Pigs were fed according to their metabolic body weight $\left(\mathrm{BW}^{0.75}\right)$ at 2.1 times the digestible energy requirements for maintenance, which were assumed to be $480 \mathrm{~kJ} / \mathrm{kg}$ $\mathrm{BW}^{0.75}$ per $\mathrm{d}$. The conversion from gross energy (Tables 1 and 2) to digestible energy was performed according to the digestibility coefficients in the Dutch feed evaluation table (Centraal Veevoeder Bureau (CVB), 2000). Feed intake was adjusted daily for a projected average daily gain of $500 \mathrm{~g}$. At the start of the adaptation period, pigs were switched to the experimental diets within two days. Feed was provided as mash and was mixed with water $(3 \mathrm{l} / \mathrm{kg}$ feed) immediately prior to feeding (viz. no soaking time).

Each experimental period was preceded by a 7-day adaptation period on the experimental diets and feeding strategy. During the adaptation and experimental periods, pigs were individually housed on a tenderfoot floor $(150 \times 60 \mathrm{~cm})$ in one of two identical, size-adjustable climatic respiration chambers. To collect faeces quantitatively, plastic bags were attached to the rear end of the pigs as described by Van Kleef et al. (1994). The ambient temperature was kept at $20^{\circ} \mathrm{C}$, relative humidity was maintained at $65 \%$, and air velocity was $<0.2 \mathrm{~m} / \mathrm{s}$. Pigs were exposed to $12 \mathrm{~h}$ of light (300 lux from 0700 to $1900 \mathrm{~h}$ ) and $12 \mathrm{~h}$ of darkness (10 lux). The experiment was approved by the Ethical Committee of Wageningen University. 
Van den Borne, Schrama, Heetkamp, Verstegen and Gerrits

Table 2 Ingredient and nutrient composition of the basal diets ${ }^{\dagger}$

\begin{tabular}{|c|c|c|c|c|c|}
\hline \multirow[b]{2}{*}{ Ingredient } & \multicolumn{2}{|c|}{ Diet } & \multirow[b]{2}{*}{ Nutrient ${ }^{\|}$} & \multicolumn{2}{|c|}{ Diet } \\
\hline & Protein & Carbohydrate & & Protein & Carbohydrate \\
\hline & \multicolumn{2}{|c|}{$(g / k g)$} & & \multicolumn{2}{|c|}{$(\mathrm{g} / \mathrm{kg})$} \\
\hline Gelatinised maize starch & 0 & 750 & Dry matter & 906 & 894 \\
\hline Potato protein & 382 & 0 & Crude ash & 62 & 45 \\
\hline Soya-protein isolate & 368 & 0 & Crude protein $(\mathrm{N} \times 6.25)$ & 672 & 20 \\
\hline Oat hulls & 90 & 90 & Crude fat & 43 & 20 \\
\hline Sugar-beet pulp & 60 & 60 & Starch & 21 & 663 \\
\hline Maize oil & 20 & 20 & Sugars & 3 & 14 \\
\hline Soya-bean oil & 20 & 20 & NSP & 105 & 131 \\
\hline $\mathrm{CaCO}_{3}$ & 12.0 & 12.0 & Gross energy (MJ/kg) & 22.1 & 17.2 \\
\hline $\mathrm{CaHPO}_{4} \cdot 2 \mathrm{H}_{2} \mathrm{O}$ & 10.0 & 10.0 & & & \\
\hline $\mathrm{NaCl}$ & 0.5 & 0.5 & Natural ${ }^{13} \mathrm{C}$ abundance, (atom \%) & 1.0814 & 1.0952 \\
\hline $\mathrm{KHCO}_{3}$ & 12.0 & 12.0 & & & \\
\hline $\mathrm{NaHCO}_{3}$ & 4.0 & 4.0 & & & \\
\hline $\mathrm{MgO}$ & 0.8 & 0.8 & & & \\
\hline DL-methionine & 0.7 & 0.7 & & & \\
\hline Diamol $^{\ddagger}$ & 10.0 & 10.0 & & & \\
\hline Pre-mix $\S^{\S}$ & 10.0 & 10.0 & & & \\
\hline
\end{tabular}

${ }^{\dagger}$ Basal diets were used as single diets for the asynchronous treatment (ASYN). For the synchronous treatment (SYN), the protein and carbohydrate diet were mixed in a ratio of 1 to 2.6 .

${ }^{\ddagger}$ Diatomaceous shell powder, $\mathrm{SiO}_{2}$, added as an indigestible marker.

$\S$ Provided per kg of the experimental diet: $5000 \mathrm{IU}$ retinol; $1000 \mathrm{IU}$ cholecalciferol; $7.5 \mathrm{mg} \alpha$-tocopherol; $15 \mu \mathrm{g}$ cyanocobalamin; $0.4 \mathrm{mg}$ phylloquinone; $3.5 \mathrm{mg}$ ribo-

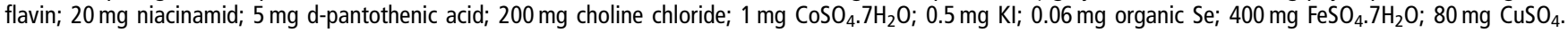
$\mathrm{H}_{2} \mathrm{O} ; 70 \mathrm{mg} \mathrm{MnO}_{2} ; 200 \mathrm{mg} \mathrm{ZnSO} \mathrm{H}_{4} \cdot \mathrm{H}_{2} \mathrm{O}$.

"Analysed content, unless indicated otherwise. Sugars were mono- and disaccharides as glucose units. NSP $=$ non-starch polysaccharide content which was calculated by subtracting the crude protein, crude fat, starch, sugars and ash content from the dry matter content.

\section{Measurements}

Pigs were weighed at the start and end of each experimental period. Gaseous exchange (carbon dioxide, oxygen and methane) was measured in pigs in 9-min intervals as described by Verstegen et al. (1987). Physical activity of pigs was recorded by a radar-Doppler device (Wenk and Van Es, 1976). On days 2 and 6 of each experimental period, air was sampled in 30-min intervals during a 24-h period from the respiration chambers in evacuated tubes (Vacutainer, Becton Dickinson, Rutherford, NJ, USA) for analysis of the ${ }^{13} \mathrm{C}$ enrichment in $\mathrm{CO}_{2}$ using a Delta $\mathrm{C}$ continuous-flow isotope ratio mass spectrometer (Finnigan MAT, Bremen, Germany).

Feed was sampled during each experimental period and refusals were collected at each feeding. Feed and refusal samples were stored at $-20^{\circ} \mathrm{C}$ until analysed. Faeces were collected quantitatively in plastic bags that were connected to the pigs and stored at $-20^{\circ} \mathrm{C}$ until analysed. Urine was collected via two funnels below the tenderfoot floor in two buckets containing $125 \mathrm{ml}$ of $4.5 \mathrm{~mol} / \mathrm{l}$ sulphuric acid each. The total amount of urine was registered and mixed at the end of each experimental period, and a sample was taken for analysis. Aerial $\mathrm{NH}_{3}$ was quantitatively trapped in $4.5 \mathrm{~mol} / \mathrm{l}$ sulphuric acid and in water that condensed on the heat exchanger (Verstegen et al., 1987).

For determination of the dry matter content, feed, feed refusals and fresh faeces were freeze-dried according to ISO 6496 (International Organization for Standardization
(ISO), 1998b). Subsequently, faeces and feed were ground to pass a 1-mm screen and kept for analyses. Air-dry faeces and feed were dried in a forced air oven at $103^{\circ} \mathrm{C}$ to a constant weight according to ISO 6496 (ISO, 1998b). Kjeldahl nitrogen content was measured according to ISO 5983 (ISO, 1997) in fresh feed, feed refusals, faeces, urine and in $\mathrm{NH}_{4}^{+}$-containing sulphuric acid and water that condensed on the heat exchanger. Crude fat content was determined after acid hydrolysis in feed and in freeze-dried faeces according to ISO 6492 (ISO, 1999). Crude ash content was determined in feed and in freeze-dried faeces. Samples were incinerated at $550^{\circ} \mathrm{C}$ in a muffle furnace according to ISO 5984 (ISO, 2002). The starch content in freeze-dried feed and faeces was analysed enzymatically as described by Rijnen et al. (2001). Gross energy content was analyzed in freeze-dried feed, faeces, and urine using adiabatic bomb calorimetry (IKA-calorimeter C7000, Staufen, Germany) according to ISO 9831 (ISO, 1998a).

Experimental diets were ground in a ball mill (Retsch MM 2000, Retsch GmbH \& Co., Haan, Germany) and ${ }^{13} \mathrm{C}$ natural abundance was measured after combustion in an elemental analyser using the continuous flow isotope ratio mass spectrometer. All analyses were carried out in duplicate, except nitrogen content in urine which was determined in triplicate.

\section{Calculations}

For each experimental period, the metabolisable energy intake (ME) was calculated per chamber as the difference 
between digestible energy intake and the sum of urinary energy loss and methane production. From the gaseous exchange, heat production $\left(\mathrm{H}_{\text {tot }}\right)$ was calculated according to the formula of Brouwer (1965). For each pig within a balance period, the energy costs per unit of physical activity were estimated by regression of physical activity against $\mathrm{H}_{\text {tot. }}$. Activity related heat production $\left(\mathrm{H}_{\mathrm{act}}\right)$ was calculated (Heetkamp et al., 1995). Heat production not related to physical activity was derived by subtracting $\mathrm{H}_{\text {act }}$ from $\mathrm{H}_{\text {tot. }}$. Energy retention was calculated by subtracting $\mathrm{H}_{\text {tot }}$ from ME intake. Nitrogen (N) retention was calculated as the difference between $\mathrm{N}$ intake and $\mathrm{N}$ output in faeces and urine. Aerial $\mathrm{NH}_{3}$ and $\mathrm{NH}_{4}^{+}$in water that condensed on the heat exchanger were included in the urinary $\mathrm{N}$ excretion. Crude protein content was calculated as $\mathrm{N} \times 6.25$. Energy retained as protein was calculated from retained protein assuming $23.6 \mathrm{~kJ} / \mathrm{g}$ of protein (McDonald et al., 1995). Energy retention as fat was calculated by subtracting energy retained as protein from energy retention. From the ME intake and energy retention as protein and fat, the $M E$ requirements for maintenance $\left(M_{m}\right)$ was calculated. An efficiency of utilization of ME for protein and fat deposition of $54 \%$ and $74 \%$ respectively was assumed (ARC, 1981). The respiratory quotient (RQ) was calculated by expressing the $\mathrm{CO}_{2}$ production relative to the $\mathrm{O}_{2}$ consumption. Balance period means were calculated for all variables and hourly means were calculated for $\mathrm{RQ}, \mathrm{H}_{\text {tot }}$ and $\mathrm{H}_{\text {act }}$. In addition, the areas under the curve were calculated for $\mathrm{H}_{\text {tot }}$ and $\mathrm{H}_{\text {act }}$ relative to their baseline to quantify the contribution of variation in $\mathrm{H}_{\text {act }}$ to variation in $\mathrm{H}_{\text {tot }}$. For $\mathrm{RQ}$, also the amplitude (i.e. the difference between maximum and minimum hourly means; $\Delta \mathrm{RQ}$ ) was calculated.

\section{Statistical analysis}

Faecal apparent digestibility and nitrogen and energy balance traits were analysed for the effect of treatment (SYN or ASYN) by ANOVA using the following model:

$$
Y_{i j}=\mu+T_{i}+P_{j}+\varepsilon_{i j}
$$

where $Y_{i j}=$ dependent variable; $\mu=$ average intercept; $T_{i}=$ effect of treatment $i(i=1,2) ; P_{j}=$ effect of pig $(j=1, \ldots, 4$ or 10$) ;$ and $\epsilon_{i j}=$ error term. Due to technical problems in the measurements of gas exchange, data from four pigs were used to estimate energy metabolism variables. Data from ten pigs were used for other variables. Therefore, effects on energy balance are not presented in the results, but briefly mentioned in the discussion section. For the analysis of all other dependent variables, all ten pigs could be used. Effects of the sequence of both treatments were separately tested but were not significant and are therefore not included in the model. Hourly means were calculated for $\mathrm{H}_{\text {tot, }} \mathrm{H}_{\text {act, }}, \mathrm{RQ}$ and ${ }^{13} \mathrm{C}$ enrichment of expired $\mathrm{CO}_{2}$ and treatment effects were tested for each hour separately. The SAS software package version 9.1 (Statistical Analysis Systems Institute Inc., Cary, NC, USA) was used in all statistical evaluations. Results are presented as least-square means with their s.e.
Table 3 Effects of synchronising amino acid and glucose availability on animal performance and on apparent nutrient digestibility in pigs ${ }^{\dagger}$

\begin{tabular}{|c|c|c|c|c|}
\hline & \multicolumn{2}{|c|}{ Treatment } & \multirow[b]{2}{*}{ s.e. } & \multirow[b]{2}{*}{$P$-value } \\
\hline & Synchronous & Asynchronous & & \\
\hline No. of pigs & 10 & 10 & - & - \\
\hline Initial body weight (kg) & 54.0 & 54.3 & 1.67 & 0.408 \\
\hline $\begin{array}{l}\text { Average daily feed } \\
\text { intake }(\mathrm{g})\end{array}$ & 1247 & 1272 & 32.8 & 0.595 \\
\hline Average daily gain (g) & 537 & 493 & 39.6 & 0.472 \\
\hline $\begin{array}{l}\text { Faecal apparent } \\
\text { digestibility }\end{array}$ & \multicolumn{2}{|c|}{$(\%)$} & & \\
\hline Dry matter & 88.1 & 86.6 & 0.52 & 0.019 \\
\hline Crude ash & 51.1 & 52.3 & 1.38 & 0.379 \\
\hline Organic matter & 90.1 & 88.7 & 0.48 & 0.011 \\
\hline Crude protein & 91.0 & 90.6 & 0.57 & 0.508 \\
\hline Crude fat & 73.7 & 69.2 & 1.70 & 0.112 \\
\hline Starch & 100.0 & 100.0 & - & - \\
\hline $\mathrm{NSP}^{\ddagger}$ & 58.3 & 45.9 & 0.35 & $<0.001$ \\
\hline Energy & 88.5 & 86.9 & 0.61 & 0.016 \\
\hline
\end{tabular}

${ }^{\dagger}$ Values are least-square means, $n=10$ for each treatment.

${ }^{\ddagger} \mathrm{NSP}=$ non-starch polysaccharides; NSP content in feed and faeces was calculated by subtracting the crude protein, crude fat, starch, sugars and ash content from the dry matter content.

\section{Results}

Average daily gain did not differ $(P>0.10)$ between treatments and averaged 515 (s.e. 26.8) g. The feed refusals, as a percentage of the feed supply, were generally low, but were twofold higher for the carbohydrate diet $(5.6 \%)$ than for the protein diet $(2.8 \%)$ in asynchronously fed pigs.

\section{Digestibility}

Apparent digestibility of dry matter, organic matter and energy was lower $(P=0.019)$ in ASYN pigs compared with SYN pigs (Table 3 ). Fat, ash and crude protein digestibility was similar in ASYN and SYN pigs. Starch was not detected in faeces of pigs fed experimental diets. Digestibility of dietary non-starch polysaccharides (NSP) was higher $(P<0.001)$ in ASYN pigs than in SYN pigs.

\section{Protein metabolism}

$\mathrm{N}$ intake was $5 \%$ higher for ASYN than for SYN $(P=0.003)$ (Table 4). Urinary $\mathrm{N}$ loss was higher $(P<0.001)$ and $\mathrm{N}$ retention was lower $(P=0.017)$ in ASYN pigs than in SYN pigs. Nitrogen balance (expressed as a percent of digestible $\mathrm{N}$ intake) was higher $(P<0.001)$ in SYN pigs $(56.7 \%)$ compared with ASYN pigs (47.1\%).

\section{Within-day substrate oxidation}

The circadian rhythm in RQ showed a considerably larger amplitude for ASYN (0.28 units) than for SYN (0.17 units) $(P<0.05$; Figure 1a). The RQ did not increase after a protein diet, whereas a synchronised diet and a carbohydrate diet resulted in an increase in RQ. The ${ }^{13} \mathrm{C}$ enrichment of $\mathrm{CO}_{2}$ in the expired air was relatively constant (1.09151.0929 atom \%) during the day in synchronously fed pigs (Figure 1b) and always exceeded the natural ${ }^{13} \mathrm{C}$ 
Van den Borne, Schrama, Heetkamp, Verstegen and Gerrits

Table 4 Effects of synchronising amino acid and glucose availability on protein metabolism in growing pigs ${ }^{\dagger}$

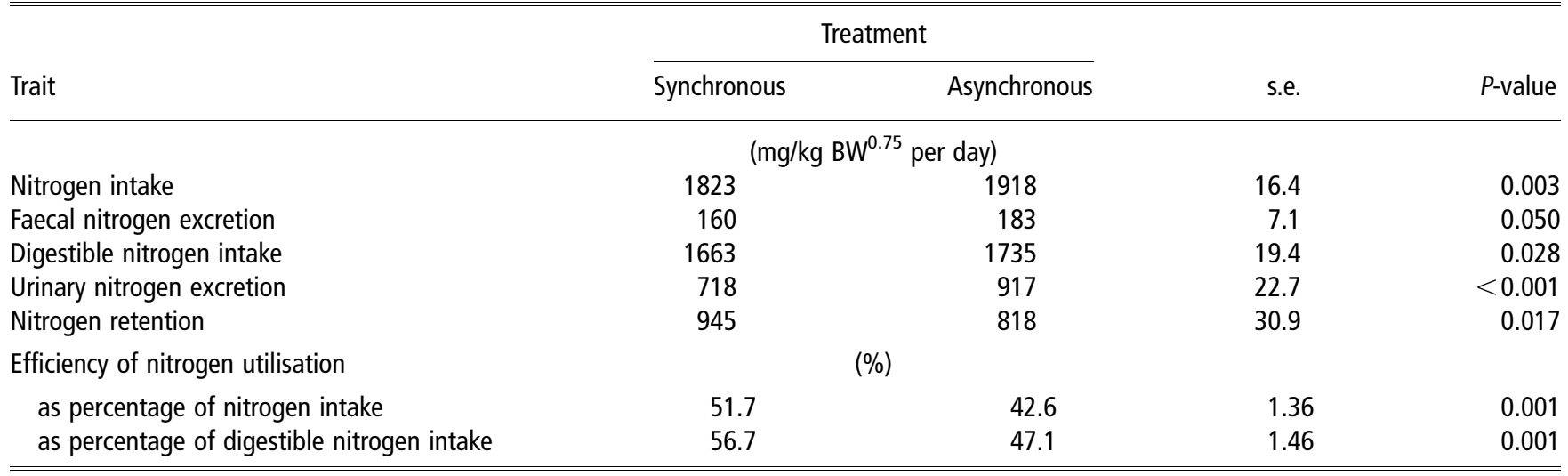

${ }^{\dagger}$ Values are least-square means, $n=10$ for each treatment.
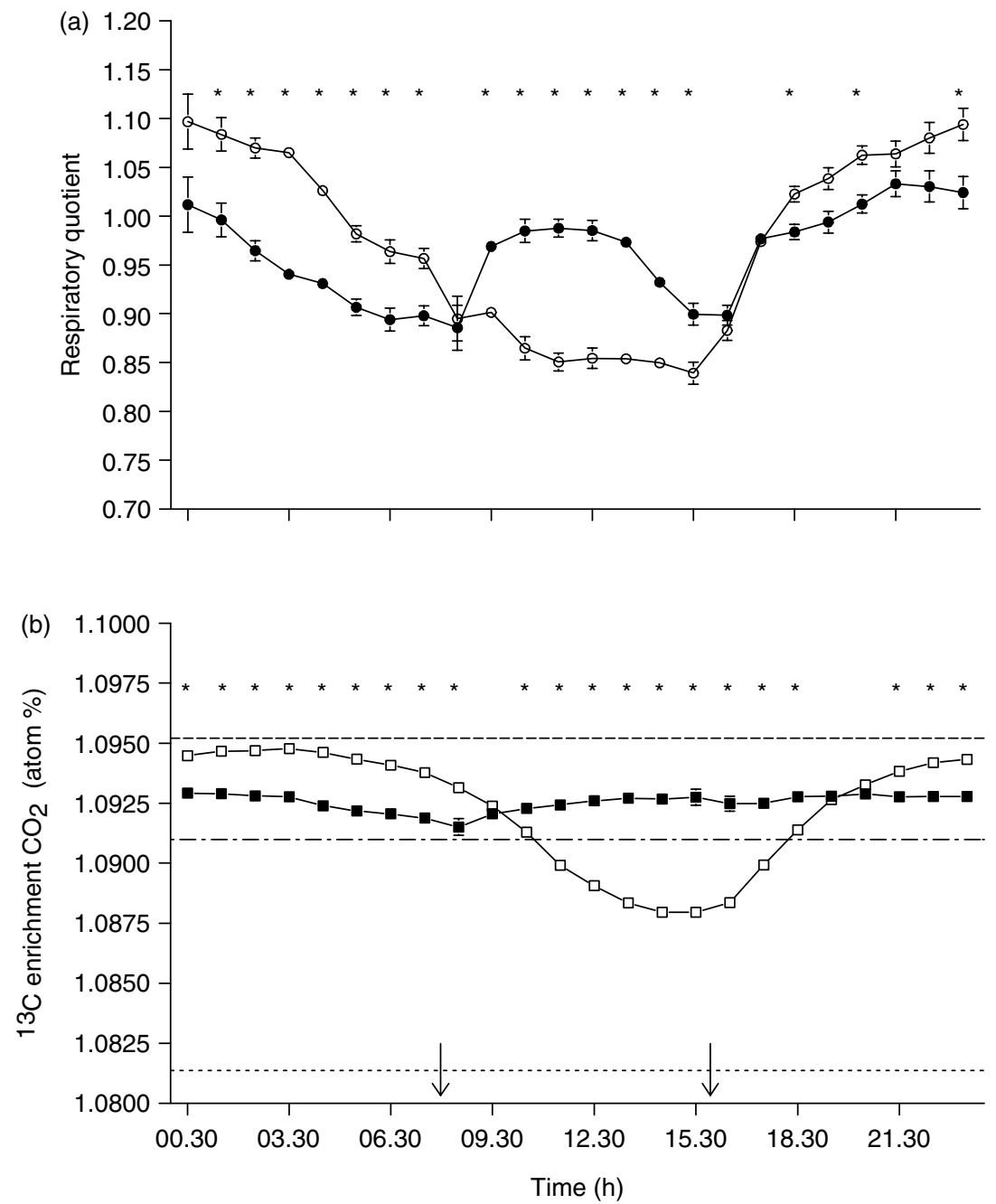

Figure 1 Effects of synchronous $(\mathbf{O}, \mathbf{\square})$ or asynchronous $(O, \square)$ availability of amino acids and glucose in growing pigs on the circadian rhythms of (a) the respiratory quotient; and $(b)$ the ${ }^{13} \mathrm{C}$ enrichment of the expired $\mathrm{CO}_{2}$. Stars indicate significance $(P<0.05)$. Results are expressed as least-square means \pm s.e., $n=4$ for each treatment. Arrows represent feeding times. Asynchronously fed pigs received a protein diet in the morning and a carbohydrate diet in the afternoon. Horizontal lines in (b) represent ${ }^{13} \mathrm{C}$ enrichment of the carbohydrate diet - - 1.0952 atom \%), the protein diet (- - - -; 1.0814 atom \%) and the synchronised diet (- - -; 1.0910 atom \%). 
abundance of the synchronised diet (1.0910 atom \%). In asynchronously fed pigs, however, the pattern of ${ }^{13} \mathrm{C}$ enrichment of $\mathrm{CO}_{2}$ within the day clearly reflected the natural ${ }^{13} \mathrm{C}$ abundance of the diet supplied.

\section{Discussion}

Digestibility

Apparent digestibility of dry matter, organic matter and energy was higher for SYN than for ASYN, which mainly originated from the increased digestibility of NSP and from the numerically increased digestibility of protein and fat. The increase in apparent digestibility of NSP for SYN compared with ASYN is related to an increase in fermentation and corresponds with a higher methane production (Table 4). This is in accordance with a higher methane production in synchronously than in asynchronously fed sows (Müller and Kirchgessner, 1996). It is speculated that the large circadian fluctuations in the substrate supply for ASYN may have changed the ratio between available carbon and nitrogen for the microflora. This may have required continuous adaptation of the microflora to their environment and decreased the ability of (large) intestinal microflora to degrade NSP. Protein digestibility was not affected by treatment and exceeded $90 \%$, which is in accordance with tabulated values for soy protein isolate and potato protein (CVB, 2000).

\section{Protein metabolism}

The higher nitrogen intake for ASYN than for SYN was caused by a higher measured protein content in the protein diet than calculated $(672 \mathrm{~g} / \mathrm{kg}$ v. $620 \mathrm{~g} / \mathrm{kg})$ in combination with slightly more feed refusals for the carbohydrate diet than for the protein diet in asynchronously fed pigs. Despite the slightly higher N intake for ASYN than for SYN, nitrogen retention and the efficiency of utilisation of digestible protein for protein gain were substantially lower for ASYN than for SYN. This does not correspond with studies in growing pigs where a partial within-day separation of corn (Eggert et al., 1953) or barley (Yeo and Chamberlain, 1966) intake from the dietary protein intake did not affect nitrogen deposition. Our results are, however, in accordance with most studies on growing subjects in other species. Protein retention decreased in children (Barja et al., 1972) and growing rats (Bancroft et al., 1951) when protein and carbohydrate intake were partially separated. A lower nitrogen retention was also found in growing rats after imposing nutrient asynchrony by feeding (Geiger et al., 1950) or intravenous infusion (Martins et al., 1985). In growing, ruminant lambs, an asynchronous abomasal infusion of amino acids and energy (i.e. triglycerides of acetate and butyrate) decreased protein retention as indicated by an increase in urea production (Randles, 2001). On the other hand, Cuthbertson et al. (1940) did not find an effect of nutrient asynchrony on nitrogen balance in growing rats, but the growth rates observed were very low
$(1 \mathrm{~g} / \mathrm{d})$ and it was argued that there may have been a dietary deficiency in that study (Geiger, 1948). In milk-fed calves, nutrient asynchrony did not decrease protein retention (Van den Borne et al., 2006).

In non-growing subjects, protein utilization generally decreases with nutrient asynchrony. In adult dogs, nitrogen balance decreased when carbohydrates were given more than 4 hours before or after a high protein diet (Larson and Chaikoff, 1937). Similar results were described when nutrient asynchrony was imposed in adult man (Cuthbertson and Munro, 1939) and adult rats (Cuthbertson et al., 1940; Munro, 1949; Van Dam-Bakker et al., 1958). In nongrowing sows, however, separation of protein and carbohydrate intake for 33 , or even for $48 \mathrm{~h}$, did not depress nitrogen balance (Müller and Kirchgessner, 1996, Kirchgessner and Müller, 1998). In 26-year-old women, a partial separation of protein and carbohydrate intake did not clearly affect protein retention, but it decreased numerically with increasing nutrient asynchrony (Arnal et al., 2000). Surprisingly, in 68-year-old women at a high protein intake, protein utilisation increased with increasing nutrient asynchrony (Arnal et al., 1999). This may be caused by an age-related impairment of the response of both protein synthesis and protein breakdown to feeding as described in adult (11 months old) and old (23 months old) rats (Arnal et al., 2002). As a consequence, an asynchronous nutrient intake was suggested to stimulate protein retention in old but not in adult rats (Arnal et al., 2002). The effect of nutrient asynchrony on $\mathrm{N}$ balance may therefore be influenced by both the degree of nutrient synchrony and the stage of maturity of the animals.

Regulation of protein utilisation by nutrient synchrony The increased urinary nitrogen losses for ASYN compared with SYN have likely resulted from an increased amino acid oxidation after the protein diet. The decreasing RQ after a protein diet (Figure 1a) suggests an increased oxidation of fat $(R Q=0.70)$ and amino acids $(R Q=0.81)$ due to a lack of glucose $(R Q=1)$ availability. Similar changes in the RQ after carbohydrate and protein diets in growing pigs were described by Charlet-Lery and Morel (1977). The increased amino acid oxidation after the protein diet could be related to the circadian rhythm of the ${ }^{13} \mathrm{C}$ enrichment of expired $\mathrm{CO}_{2}$, which was nearly invariable for SYN but showed clear fluctuations for ASYN (Figure 1b). Although firm evidence can only be obtained from direct measurement of the amino acid oxidation flux, the decrease in ${ }^{13} \mathrm{C}$ enrichment for ASYN during daytime strongly suggests that the contribution of amino acid oxidation to total substrate oxidation was substantially increased during this period. The ${ }^{13} \mathrm{C}$ enrichment of body protein, glycogen and adipose tissues were not measured and the contribution of their oxidation to total substrate oxidation could not be quantified. It can, however, quite safely be assumed that the enrichment of the protein diet is reflected in body protein, because pigs were fed exclusively proteins from C3 plants during the growing period 
prior to the study. The ${ }^{13} \mathrm{C}$ enrichment of body fat can be assumed to be only slightly lower than the natural ${ }^{13} \mathrm{C}$ abundance of the carbohydrate diet, because fat deposition mainly originates from dietary glucose (high natural ${ }^{13} \mathrm{C}$ abundance) and dietary fat (intermediary natural ${ }^{13} \mathrm{C}$ abundance). It is therefore concluded from the circadian rhythms of $\mathrm{RQ}$ and $\mathrm{CO}_{2}$ enrichment that amino acids are oxidized in absence of glucose. Several potential mechanisms for the increased amino acid oxidation with decreasing nutrient synchrony can be suggested.

First, amino acids may be used to provide ATP for maintenance and for protein deposition or for gluconeogenesis in the absence of glucose from dietary origin. Second, glucose may interact with amino acid metabolism via endocrine responses. To increase the retention of dietary amino acids and inhibit gluconeogenesis, insulin secretion should be in synchrony with the post-absorptive supply of amino acids (Fuller et al., 1977; Barthel and Schmoll, 2003). Third, the presence of dietary carbohydrates may affect amino acid metabolism in the intestinal tissues with concurrent implications for the kinetics of amino acid availability to extra-intestinal tissues (Mariotti et al., 2000; Soeters et al., 2001; Bos et al., 2003).

\section{Energy metabolism}

Unfortunately, data on energy partitioning could not be used for all pigs, because problems with the measurement of gas exchange occurred. However, the efficiency of digestible protein utilisation corresponded between the eight observations included in the data on energy balance and all 20 observations; 56.6 v. $56.7 \%$ for SYN and $46.9 v$. $47.1 \%$ for ASYN respectively. This suggests that net protein utilisation was similar between the observations from the total study and observations that could be used for calculation of energy balance (Table 5). For the latter, gross energy intake did not differ between treatments, but $D E$ intake was $50 \mathrm{~kJ} / \mathrm{kg} \mathrm{BW}^{0.75}$ per day lower for ASYN than for SYN. The $61 \mathrm{~kJ} / \mathrm{kg} \mathrm{BW}^{0.75}$ per day lower ME intake combined with an $11 \mathrm{~kJ} / \mathrm{kg} \mathrm{BW}^{0.75}$ per day lower heat production for ASYN than for SYN resulted in a tendency for a lower energy retention $\left(-50 \mathrm{~kJ} / \mathrm{kg} \mathrm{BW}^{0.75}\right.$ per day) for ASYN than for SYN. Despite the $61 \mathrm{~kJ} / \mathrm{kg} \mathrm{BW}^{0.75}$ per day lower ME intake for ASYN than for SYN, $\mathrm{H}_{\text {tot }}$ was only $11 \mathrm{~kJ} / \mathrm{kg} \mathrm{BW}{ }^{0.75}$ per day lower for ASYN than for SYN. If $\mathrm{H}_{\mathrm{act}}$ was excluded, the corrected heat production was numerically even higher for ASYN $\left(547 \mathrm{~kJ} / \mathrm{kg} \mathrm{BW}^{0.75}\right.$ per day) than for SYN $\left(542 \mathrm{~kJ} / \mathrm{kg} \mathrm{BW}^{0.75}\right.$ per day). This indicates that a substantial part of the increased quantity of deaminated amino acids for ASYN when compared with SYN was oxidised and not deposited as fat.

From Figure $1 \mathrm{a}$, it is clear that there was considerable variation in RQ between treatments within the day. An RQ greater than 1 indicates conversion of glucose into fat. The $\mathrm{RQ}$ exceeded unity after the $1600 \mathrm{~h}$ meal for $11 \mathrm{~h}$ for ASYN and for only $5 \mathrm{~h} /$ day for SYN. A low RQ, on the other hand, suggests increased rates of fatty acid (and amino acid) oxidation in the morning and early afternoon for ASYN when compared with SYN (Figure 1a), providing support for the numerically $(17 \%)$ reduced fat deposition for ASYN.

In conclusion, a virtually complete separation of protein and carbohydrate intake within a day decreased the faecal apparent digestibility of dry matter, organic matter, energy and NSP. The efficiency of digestible protein utilisation for protein retention decreased from $57 \%$ to $47 \%$ with decreasing nutrient synchrony in growing pigs. The energy yield from the increased amino acid degradation was largely lost as heat. Within the day, more prolonged periods of de novo fatty acid synthesis occurred for ASYN than for SYN,

Table 5 Effects of synchronising amino acid and glucose availability on energy metabolism in growing pigs ${ }^{\dagger}$

\begin{tabular}{|c|c|c|c|c|}
\hline \multirow[b]{2}{*}{ Trait } & \multicolumn{2}{|c|}{ Treatment } & \multirow[b]{2}{*}{ s.e. } & \multirow[b]{2}{*}{$P$-value } \\
\hline & Synchronous & Asynchronous & & \\
\hline \multicolumn{5}{|c|}{$\left(\mathrm{kJ} / \mathrm{kg} \mathrm{BW}{ }^{0.75}\right.$ per day) } \\
\hline Gross energy intake & 1099 & 1095 & 3.3 & 0.386 \\
\hline Digestible energy intake (DE) & 979 & 929 & 10.4 & 0.007 \\
\hline Urinary energy & 28 & 40 & 2.7 & 0.023 \\
\hline Methane production & 3.7 & 2.0 & 0.55 & 0.048 \\
\hline Metabolisable energy intake (ME) & 947 & 886 & 12.7 & 0.009 \\
\hline ME:DE (\%) & 96.7 & 95.4 & 0.33 & 0.025 \\
\hline Heat production & 653 & 642 & 13.8 & 0.618 \\
\hline Activity related heat production & 110 & 96 & 4.2 & 0.100 \\
\hline Activity corrected heat production & 543 & 546 & 14.7 & 0.886 \\
\hline Energy retention & 294 & 244 & 28.9 & 0.058 \\
\hline Energy retention as protein & 138 & 115 & 8.2 & 0.055 \\
\hline Energy retention as fat & 156 & 129 & 27.3 & 0.263 \\
\hline ME for maintenance & 484 & 501 & 30.6 & 0.719 \\
\hline Respiratory quotient (RQ) & 0.96 & 0.97 & 0.008 & 0.338 \\
\hline$\Delta \mathrm{RQ}^{\ddagger}$ & 0.17 & 0.28 & 0.002 & 0.027 \\
\hline
\end{tabular}

${ }^{\dagger}$ Values are least-square means, $n=4$ for each treatment.

${ }^{\ddagger} \Delta \mathrm{RQ}$ : the amplitude (maximum hourly mean minus minimum hourly mean) of the RQ. 
combined with increased rates of fatty acid oxidation for ASYN than for SYN during the remainder of the day.

\section{Acknowledgements}

The authors thank Karin Frijters, Marjolein de Haan, Koos van der Linden, Tamme Zandstra and the personnel of the experimental farm 'De Haar' for their contribution to the experiment. The laboratory staff of the Animal Nutrition Group is gratefully acknowledged for their help in chemical analyses.

\section{References}

Agricultural Research Council 1981. The nutrient requirements of pigs. Commonwealth Agricultural Bureaux, Slough, UK.

Arnal MA, Mosoni L, Boirie Y, Houlier ML, Morin L, Verdier E, Ritz P, Antoine $J M$, Prugnaud J, Beaufrère B and Patureau-Mirand $P$ 1999. Protein pulse feeding improves protein retention in elderly women. American Journal of Clinical Nutrition 69, 1202-1208.

Arnal MA, Mosoni L, Boirie $Y$, Houlier ML, Morin L, Verdier E, Ritz P, Antoine $J M$, Prugnaud J, Beaufrère $B$ and Patureau-Mirand $P$ 2000. Protein feeding pattern does not affect protein retention in young women. Journal of Nutrition 130, 1700-1704.

Arnal MA, Mosoni L, Dardevet D, Ribeyre MC, Bayle G, Prugnaud J and Patureau-Mirand P 2002. Pulse protein feeding pattern restores stimulation of muscle protein synthesis during the feeding period in old rats. Journal of Nutrition 132, 1002-1008.

Bancroft RW, Geiger E and Hagerty EB 1951. Nitrogen-sparing effect of carbohydrate related to time factor with hypophysectomized and diabetic rats. Endocrinology 49, 149-153.

Barja I, Araya H, Munoz P, Vega L, Arteaga A and Tagle MA 1972. Effect of spacing protein intake on nitrogen balance in normal children. The American Journal of Clinical Nutrition 25, 506-511.

Barthel A and Schmoll D 2003. Novel concepts in insulin regulation of hepatic gluconeogenesis. The American Journal of Physiology 285, E685-E692.

Bos C, Metges CC, Gaudichon C, Petzke KJ, Pueyo ME, Morens C, Everwand J, Benamouzig R and Tomé D 2003. Postprandial kinetics of dietary amino acids are the main determinant of their metabolism after soy or milk protein ingestion in humans. The Journal of Nutrition 133, 1308-1315.

Brouwer E 1965. Report of sub-committee on constants and factors. In Energy metabolism (ed. KL Blaxter), pp. 441-443. Academic Press, London, UK.

Campbell RG and Taverner MR 1988. Genotype and sex effects on the relationship between energy intake and protein deposition in growing pigs. Journal of Animal Science 66, 676-686.

Charlet-Lery G and Morel MT 1977. Influence of diet on respiratory quotients and fat deposition in growing pigs. Annales de Biologie Animale, Biochimie, Biophysique 17, 897-904.

Cummings JH and Englyst HN 1995. Gastrointestinal effects of food carbohydrate. The American Journal of Clinical Nutrition 61, 938S-945S.

Cuthbertson DP and Munro HN 1939. The relationship of carbohydrate metabolism to protein metabolism. I. The roles of dietary carbohydrate and of surfeit carbohydrate in protein metabolism. The Biochemical Journal 33, 128-142.

Cuthbertson DP, McCutcheon A and Munro HN 1940. The relationship of carbohydrate metabolism to protein metabolism. 2. Note on the effect of separation in time of the protein and carbohydrate moieties of the diet of the adult and growing rat. The Biochemical Journal 34, 1002-1007.

Centraal Veevoeder Bureau 2000. Veevoedertabel. Lelystad, The Netherlands.

Eggert RG, Brinegar MJ and Anderson CR 1953. Delayed protein supplementation of corn diets for growing swine. The Journal of Nutrition 50, 469-477.

Eits RM, Kwakkel RP, Verstegen MWA, Stoutjesdijk P and De Greef KH 2002. Protein and lipid deposition rates in male broiler chickens: separate responses to amino acids and protein-free energy. Poultry Science 81, 472-480.

Englyst KN, Vinoy S, Englyst HN and Lang V 2003. Glycaemic index of cereal products explained by their content of rapidly and slowly available glucose. The British Journal of Nutrition 89, 329-340.
Fuller MF, Weekes TEC, Cadenhead A and Bruce JB 1977. The protein-sparing effect of carbohydrate 2. The role of insulin. The Journal of Nutrition 38, 489-496.

Geiger E 1948. The importance of the time element in feeding of growing rats. Experiments with delayed supplementation of protein. Science 108, 42-43.

Geiger E, Bancroft RW and Hagerty EB 1950. The nitrogen-sparing effect of dietary carbohydrate in its relation to the time factor: experiments with repletion of protein-depleted adult rats. The Journal of Nutrition 42, 577-585.

Gerrits WJJ, Tolman GH, Schrama JW, Tamminga S, Bosch MW and Verstegen MWA 1996. Effect of protein and protein-free energy intake on protein and fat deposition rates in preruminant calves of 80 to $240 \mathrm{~kg}$ live weight. Journal of Animal Science 74, 2129-2139.

Heetkamp MJW, Schrama JW, de Jong L, Swinkels JW, Schouten WG and Bosch MW 1995. Energy metabolism in young pigs as affected by mixing. Journal of Animal Science 73, 3562-3569.

International Organization for Standardization 1997. Animal feeding stuffs. Determination of nitrogen content and calculation of crude protein content. Kjeldahl method. ISO 5983. ISO, Geneva.

International Organization for Standardization 1998a. Animal feeding stuffs, animal products, and faeces or urine. Determination of gross calorific value. ISO 9831. ISO, Geneva.

International Organization for Standardization 1998. Animal feeding stuffs. Determination of moisture and other volatile matter content. ISO 6496. ISO, Geneva.

International Organization for Standardization 1999b. Animal feeding stuffs. Determination of fat content. ISO 6492. ISO, Geneva.

International Organization for Standardization 2002. Animal feeding stuffs. Determination of crude ash. ISO 5984. ISO, Geneva.

Kirchgessner M and Müller HL 1998. Dietary separation of protein and carbohydrate intake. In Energy metabolism in farm animals (ed. KJ McCracken, EF Unsworth and ARG Wylie), pp. 135-138. CAB International, Wallingford, UK.

Larson PS and Chaikoff IL 1937. The influence of carbohydrate on nitrogen metabolism in the normal nutritional state. The Journal of Nutrition 13, 287-304.

Longenbach JI and Heinrichs AJ 1997. A review of the importance and physiological role of curd formation in the abomasum of young calves. Animal Feed Science and Technology 73, 85-97.

Mariotti F, Huneau JF, Mahé S and Tomé D 2000. Protein metabolism and the gut. Current Opinion in Clinical Nutrition and Metabolic Care 3, 45-50.

Martins FM, Sandberg G, Ekman L and Lindmark L 1985. Metabolic response of simultaneous versus sequential intravenous administration of amino acids and energy substrates to rats. The American Journal of Clinical Nutrition 42, 61-68.

McDonald P, Edwards RA, Greenhalgh JFD and Morgan CA 1995. Animal nutrition. Pearson Education Limited, Harlow, UK.

Metges CC, El-Khoury AE, Selvaraj AB, Tsay RH, Atkinson A, Regan MM, Bequette BJ and Young VR 2000. Kinetics of $\mathrm{L}-1-{ }^{13} \mathrm{C}$-Leucine when ingested with free amino acids, unlabeled or intrinsically labelled casein. The American Journal of Physiology 278, E1000-E1009.

Mosoni L and Patureau-Mirand P 2003. Type and timing of protein feeding to optimize anabolism. Current Opinion in Clinical Nutrition and Metabolic Care 6, 301-306.

Müller HL and Kirchgessner M 1996. Effect of chronological separation of protein and carbohydrates by up to $48 \mathrm{~h}$ on the energy metabolism [in German]. Journal of Animal Physiology and Animal Nutrition 76, 1-8.

Munro HN 1949. The relationship of carbohydrate metabolism to protein metabolism. The Journal of Nutrition 39, 375-391.

Munro HN 1964. General aspects of the regulation of protein metabolism by diet and by hormones. In Mammalian protein metabolism (ed. HN Munro and JB Allison), pp. 381-481. Academic Press, London.

Randles WG, 2001 The effects of different temporal patterns of post-ruminal energy and protein supply on nitrogen metabolism in growing lambs, Doctoral thesis, University of Aberdeen, Aberdeen, UK.

Rijnen MMJA, Verstegen MWA, Heetkamp MJW and Schrama JW 2001. Effects of dietary fermentable carbohydrates on energy metabolism in grouphoused sows. Journal of Animal Science 79, 148-154.

Soeters PB, Dejong CH and Deutz NEP 2001. The protein sparing function of the gut and the quality of food protein. Clinical Nutrition 20, 97-99.

Van Dam-Bakker AWI, De Groot AP and Luyken R 1958. The influence of alternate high-protein and low-protein feeding on growth and reproduction 
and on regeneration of haemoglobin in rats. The British Journal of Nutrition $12,259-266$.

Van den Borne JJGC, Verstegen MWA, Alferink SJJ, Van Ass FHM and Gerrits WJJ 2006. Synchronizing the availability of amino acids and glucose decreases fat retention in heavy preruminant calves. The Journal of Nutrition 136, 2181-2187.

Van der Meulen J, Bakker JGM, Smits B and De Visser H 1997. Effect of source of starch on net portal flux of glucose, lactate, volatile fatty acids and amino acids in the pig. The British Journal of Nutrition 78, 533-544.

Van Kleef DF, Deuring K and Van Leeuwen P 1994. A new method for faeces collection in the pig. Laboratory Animals 28, 78-79.
Verstegen MWA, Van der Hel W, Brandsma H, Henken AM and Bransen AM 1987. The Wageningen respiration unit for animal production research: a description of the equipment and its possibilities. In Energy metabolism in farm animals: effects of housing, stress and disease (ed. MWA Verstegen and AM Henken), pp. 21-48. Martinus Nijhoff Publishers, Dordrecht, The Netherlands.

Wenk C and Van Es AJH 1976. Eine Methode zur Bestimmung des Energieauswandes für die körperlich Aktivität von wachsenden Küken. Schweizerische Landwirtschaftliche Monatshefte 54, 232.

Yeo ML and Chamberlain AG 1966. Delayed protein supplementation of barley diets for weanling pigs. The Proceedings of the Nutrition Society 25, 41. 